\title{
Evaluation of Pb Metal in Organic Waste and Cattle Grazed in Tamangapa Landfill, Makassar, South Sulawesi, Indonesia
}

\author{
${ }^{1}$ Rahmawati, ${ }^{2}$ Ambo Ako, ${ }^{2} J a m i l a, ~ 3$ Purnama Isti Khaerani, ${ }^{1}$ Sema, ${ }^{2}$ Syamsuddin Hasan \\ ${ }_{1}^{1}$ Postgraduate of Animal Science Department, University of Hasanuddin \\ ${ }^{2}$ Animal Science Department, University of Hasanuddin \\ ${ }^{3}$ Bachelor Degree of Animal Science Department, University of Hasanuddin
}

Received date: 19 April 2018, Accepted date: 15 June 2018, Online date: 29 June 2018

Address For Correspondence:

Rahmawati, Postgraduate student of Animal Science Department, University of Hasanuddin,Makassar, 90245, Indonesia E-mail:sekar.rahmah@yahoo.co.id

Copyright $\odot 2018$ by authors and American-Eurasian Network for Scientific Information. This work is licensed under the Creative Commons Attribution International License (CC BY). http://creativecommons.org/licenses/by/4.0/

\section{(C) (i) Open Access}

\begin{abstract}
In Tamangapa landfill, the cattle consume organic waste as the feed which is susceptible to be contaminated by $\mathrm{Pb}$ metal. When the feed is consumed, $\mathrm{Pb}$ metal accumulated in the body cattle, it can be endanger the health of the cattle even the people who consume the meat. This study was aimed to measure and examine the content of $\mathrm{Pb}$ metal in the cattle which grazed inside and outside the landfill. This study materials included organic feed, leachate water, blood and feces from five cattle that grazed inside and outside the landfill, as samples. Pb metal testing to the samples was performed by using Atomic Absorption Spectrophotometric (SSA) method. The results of analyses described as follows: (a) in the waste feed was found the $\mathrm{Pb}$ metal contents are $0.99 \mathrm{ppm}$ and $0.16 \mathrm{ppm}$ inside and outside the landfill, respectively. (b) in blood cattle were $2.75 \mathrm{ppm}$ and $1.98 \mathrm{ppm}$ for grazing inside and outside the landfill, respectively. It should be notable that in both places, the Pb metal content in the blood cattle exceed the standard value $0.1 \mathrm{ppm}$. (c) In.feces cattle was $2.014 \mathrm{ppm}$ and $1.27 \mathrm{ppm}$ for the cattle that grazed inside and outside the landfill, respectively. the was no difference of the $\mathrm{Pb}$ metal level in the blood cattle, however, the difference of the average of $\mathrm{Pb}$ metal content in beef feces cattle has been found. Thus, it is concluded that the organic waste in the Tamangapa landfill is feasible as cattle feed but leachate water which as a source of drinking water is not feasible to consume by the cattle. Pb metal contenton blood cattlegrazed inside and outside the landfill is differ respectively, However, the $\mathrm{Pb}$ contenton feces cattle in inside the landfill is higher than outside the landfill.
\end{abstract}

KEYWORDS

$\mathrm{Pb}$ Metal, cattle, landfill

\section{INTRODUCTION}

Tamangapa landfill is the final dumping place for all waste in Makassar City since 1992. With a land area of $\pm 16.8 \mathrm{ha}$, the garbage is managed from the source to final stage in management and disposal. [1] Showed that the physical characteristics and composition of garbage in the landfill consist of organic $80,71 \%$ waste, 9,23\% plastic, $7.03 \%$ paper, $0.03 \%$ fabric, $0,17 \%, 0.22 \%$ glass, $2.12 \%$ cans/iron, $0.50 \%$ rubber. Generally, garbage comes from the market, household and other public waste, because of organic waste abundance in the landfill, the farmers use it as feed source. Based on [2] in 2015, the cattle that grazed in Tamangapa landfill reaches 1,600 population. This amount shows the higher interest of the farmers, the higher effort to herd their beef cattle in the landfill.

Waste can be categorized into organic and inorganic waste [3]. In a landfill, there are often some kinds of waste that are not cattle feed, such as plastic bags, rubber sandals, paper, and so forth, but consumed by cattle. This may cause the cattle vulnerable to be contaminated with $\mathrm{Pb}$, aside from the main natural or anthropogenic 
source of $\mathrm{Pb}$ metal [4]. The source of $\mathrm{Pb}$ metal in farm area can come from air, water and animal feed as well [5] and increased contaminant levels in the marine environment [6]. Conventionally, $\mathrm{Pb}$ is a heavy metal that often causes poisoning in ruminants. In cattle body, the metal is absorbed by the blood, thereafter binding to the blood protein which is distributed throughout the body tissues [7]. Heavy metals are chemical compounds that can enter through the food and accumulate in the body within a certain period of time and then can cause health problems to the cattle [8]. Heavy metals can also cause disturbance effects on human health, depending on the location and dose of exposure to metals. Toxic effects of heavy metals will be able to inhibit the action of enzymes, and therefore, their presence in human or animal body can interfere the body metabolism that will cause such allergies, mutagenic, teratogens or carcinogens [9]. Various types of decomposed waste will produce leachate which is as a source of drinking water for the cattle that grazed in the landfill. However, leachate can consist of organic materials as well as inorganic materials where the inorganic materials may include heavy metals such as $\mathrm{Pb}$ and $\mathrm{Cd}[10]$

[11] Showed that the content in the blood of cattle that grazed in the mining area in Nigeria, averagely of $5.7550 \mathrm{ppm}$ and on the surrounding area, the average level of $\mathrm{Pb}$ in vegetables, soil and water were 51.343, 46.039 and $1.301 \mathrm{ppm}$ respectively. Pb levels in vegetables and fruits are higher in industrial areas than those on the highway pathways, and the lowest in rural areas showed that in Egypt, Pb level in organ cattle (i.e. meat, liver, kidney, lymph and heart) were highest in the industrial areas and highways and lows in rural as well [12].

The garbage in Tamangapa landfill consists of organic and inorganic waste which can be contaminated by $\mathrm{Pb}$ metal and could be a toxic when they are consumed by the cattle. Based on this reason, an investigation on content of $\mathrm{Pb}$ in feed and drinking water source in Tamangapa landfill should be conducted. The investigation was performed by examining and comparing the content of $\mathrm{Pb}$ in blood and feces of the cattle that grazed inside and outside the landfill.

\section{MATERIAL AND METHOD}

1. This research was conducted from March to July 2018 in Tamangapa landfill and the surrounding area. Meanwhile, $\mathrm{Pb}$ analysis was carried out at Chemical and Livestock Feed Laboratory of Animal Feed, Faculty of Animal Science, Hasanuddin University, Makassar.

2. In this study we used the materials as follows: organic waste from Tamangapa landfill, blood and feces of cattle that grazed inside and outside the landfill. The materials have been used for $\mathrm{Pb}$ analysis. During a period of collecting and analyzing the materials, we use some tools like plastic enclosures/ plastic containers where feed and feces and Leachate samples, tube spoit and syringes, test tubes (EDTA), and tools used for Pb analysis based on [13] and Quantification [114]

Feed samples are a mixture of new garbage and old garbage was taken for 5 consecutive days when the cattle was grazed at the landfill. The new waste is related to the new garbage down from the garbage truck while the old waste to the garbage that has been mixed with the soil and other old garbage, the garbage is then homogenized, weighed \pm 300 grams/day, dried and then put into plastic enclosures. On the fifth day, all of the waste samples are homogenized. The leachate water was been taken with plastic tube each $\pm 100 \mathrm{ml}$ at three locations, that is, in outer-, middle-, and near the center of garbage disposal. And then the content of $\mathrm{Pb}$ in both samples of garbage and leachate feed was analyzed.

Five cattle those aged over two years that grazed in the landfill since calf period has been used as cattle sample. The blood cattle was taken in their jugular vein by using $5 \mathrm{ml}$ spoit needle, and then, their blood sample was inserted into vacuum tube (EDHA) that contain anticoagulant. The fecal samples \pm 300 gram/cattle, and then put into a closed plastic container. To keep the temperature stable, blood and feces samples are fed into the cool box then taken to the Laboratory for analysis. Testing of $\mathrm{Pb}$ level on blood and fecal samples were perform by using Atomic Absorption Spectrophotometric Method based on [13] and Quantification [14]. For a comparison, blood samples and feces fecal from five cattle that grazed outside the landfill by using similar techniques as described above.

Analysis of data on blood and feces of cattle that grazed inside and outside the landfill were performed by using statistical test of Hypothesis of Independent Sample, T-test. The results of heavy metals analysis on feed and cattle were then compared with prevailing food safety standards.

\section{RESULT AND DISCUSSION}

Table 1: Pb content in organic waste feed and Leachate in Tamangapa landfill, Makassar.

\begin{tabular}{|l|l|}
\hline \multicolumn{1}{|c|}{ Samples } & $\mathrm{Pb}$ content $(\mathrm{ppm})$ \\
\hline Organic waste feed & 0.99 \\
\hline Leachate & 0.16 \\
\hline
\end{tabular}

Table 1 showed that content of $\mathrm{Pb}$ metal in organic waste and leachate in Tamangapa landfill, Makassar. We found that content of $\mathrm{Pb}$ in the waste is about $0.99 \mathrm{ppm}$. This value is lower than maximum standard of $\mathrm{Pb}$ 
metal tolerated in the feed (National Research Council, Canada) [15] and Indonesian National Standard (SNI) 3148.2:2009 [16]. However, the content of $\mathrm{Pb}$ in leachate about 0, $16 \mathrm{ppm}$, higher than standard drinking water of World Health Organization [, Indonesian National Standard (SNI) 7388:2009 [16] and NRC (National Research Council, Canada) [15].

The content of $\mathrm{Pb}$ found in the organic feed at Tamangapa landfill is not different greatly with investigation [17] that found $\mathrm{Pb}$ content in garbage at Jatibarang landfill is about $0.42-1.63 \mathrm{ppm}$ which is lower than in old waste, 13.98-7.09 ppm. Pb content in organic waste feed at Putri Cempo landfill about 12,34 ppm [18]. Tolerance of $\mathrm{Pb}$ content in animal feed typically is about $30 \mathrm{mg} / \mathrm{kg}$ [19]. Although $\mathrm{Pb}$ content in organic waste feed at Tamangapa landfill is low, but $\mathrm{Pb}$ can accumulate in cattle bodies. The grass contaminated by heavy metals could be a cause of heavy metal accumulation in the body of cattle consuming it [20]. Organic waste feed was consumed by cattle such as banana peel, corncob, vegetable stem, spinach, mustard and banana leaf, eggshell, wheat flour, vegetable cut, residual food and various types of crops. Organic waste then mixed with inorganic waste such as plastic, rubber, food packaging paper and so forth. Chronic poisoning will be occurred when heavy metals consumed in a long time and continuously, even though in low doses [19]. Pb poisoning can be occurred since the $\mathrm{Pb}$ able to change protein that will inhibit calcium absorption and replace zinc as an enzyme [21]. Considerable high content of heavy metal such as $\mathrm{Pb}$ metal has been reported as a result of several industrial or waste disposal activities in some regions [22]. We found that the content of $\mathrm{Pb}$ in leachate water in Tamangapa landfill higher than that found in Jatibarang, 0.082-0.096 ppm[17].Meanwhile, the maximum limit of $\mathrm{Pb}$ in the drinking water that recommended 23] [24] [16] are 0.05, 0.1, and $0.01 \mathrm{ppm}$ respectively. The content of $\mathrm{Pb}$ in leachate water at Tamangapa landfill indicate that leachate water is not suitable to be a source of drinking water for the cattle. In addition, the leachate water smells and blackish brown. The decomposition process produce leachate, where the leachate contain organic as well as inorganic materials. In this case, inorganic materials may contain heavy metals such as $\mathrm{Pb}$ and $\mathrm{Cd}$ [8]. When the cattle consumed leachate for the long term, $\mathrm{Pb}$ metal will be accumulated in the cattle's body.Therefore, it needsto be ccareful attention for feeding to livestock [22].

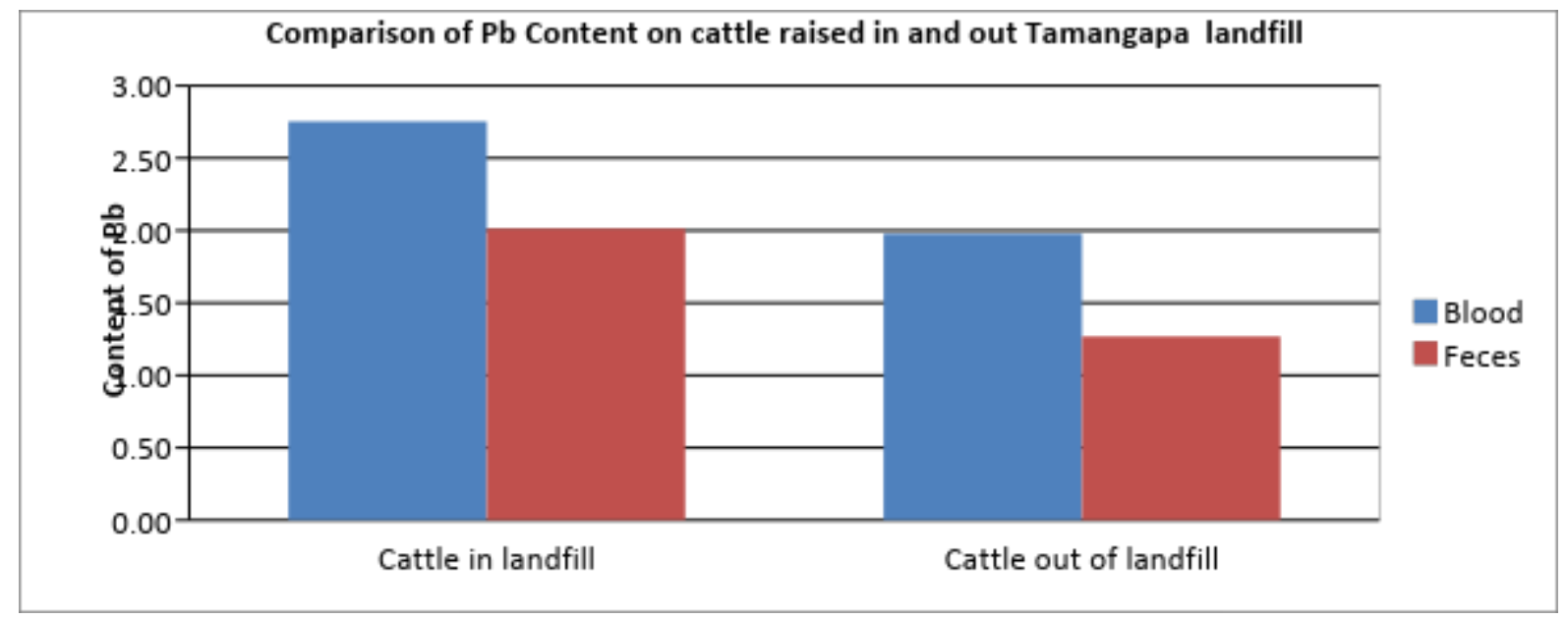

Source : Livestock Feed Chemical Laboratory, Hasanuddin University, 2018

Graphic 1: Pb contenton organ catte that raised in and outside Tamangapa landfill, Makassar.

Graphic 1 showed that contenton blood and feces of cattle that grazed inside are higher than outside the landfill. However, both location are higher than standard of $\mathrm{Pb}$ level for the cattle needs. The average $\mathrm{Pb}$ content in the blood was $2.75 \mathrm{ppm}$ and $1.98 \mathrm{ppm}$ that grazed inside and outside the landfill respectively. The content of $\mathrm{Pb}$ on feces cattle were $2.01 \mathrm{ppm}$ and $1.27 \mathrm{ppm}$ inside and outside the landfill, respectively.

Independent sample $\mathrm{T}$-test showed that $\mathrm{Pb}$ level of cattle organ that grazed both inside and outside the landfillwas not differ respectively. By this research, we observed that organic waste feed did not significantly affect the content of $\mathrm{Pb}$. However, leachate water as a source of drinking water significantly contribute to $\mathrm{Pb}$ content on organ cattle that grazed in the Tamangapa landfill.

Pbcontent was found on blood cattlethat grazed in the landfill is higher than the out of the landfill. However, those indicate an existence of $\mathrm{Pb}$ metal in body cattle. $\mathrm{Pb}$ content in cow blood in Suwung Denpasar TPA varies between 0 and $10.291 \mathrm{ppm}$ [25]. grazing cattle in open area showed that average of Pb content in blood cattle is $0.129 \mathrm{ppm}$, which is higher than the WHO standard value about $0.01 \mathrm{ppm}$ [26]. These high content may be due to high contents of pollutants in those areas. For grazing cattle in Tamangapa landfill, $\mathrm{Pb}$ 
metal comes from leachate water, in addition from inorganic waste that consumed by cattle accidentally. The habit of licking by ruminant sometimes can be a main cause of poisoning [7]. $\mathrm{Pb}$ source can be found in garbage and around farm building. Wrapping paper can contain $\mathrm{Pb} 10 \mathrm{~g} / \mathrm{kg}$, plastic made of food wrap paper $20 \mathrm{mg} / \mathrm{kg}$, and candy wrappers $7 \mathrm{~g} / \mathrm{kg}$ as well [27]. Pb source also can be found on HVS paper $6.013 \mathrm{ug} / \mathrm{g}$, printing ink $2.012 \mu \mathrm{g} / \mathrm{ml}$, and fried-food packaging paper $10,466 \mu \mathrm{g} / \mathrm{ml}$ [28]. There is possibility cattle exposed to vehicle fumes on the way from pen to landfill that could be a contributor for Pb content. Heavy metal levels foundin some fish species were higher than other samples from Aladja River. Bioaccumulation may be responsible for this observation [29].

For cattle that grazed in outside the landfill, contamination may be derived from concentrates. Contamination of additional feed ingredients commonly used on cattle such as fish meal, bone meal and powdered flour can lead to increased heavy metal contamination [20]. Heavy metal $\mathrm{Pb}$ in poultry feed in Texas shows average $\mathrm{Pb}$ content is about $0.14 \mathrm{mg} / \mathrm{kg}$ [30]. Although cattle was grazed in outside the landfill, feed sources in the form of forage are close to highway. Research found that organ such as liver from cattle where grazing in Deli Serdang consuming wild grass as a feed source of Pb concentration is about 1.080 ppm.when cattle grazed around roadsidewildly will be contaminated until $1.230 \mathrm{ppm}$. It is caused by vehicle exhaust emissions that contain $\mathrm{Pb}$. $\mathrm{Pb}$ poisoning is often found in livestock farms, especially in livestock that grazed by grazing systems around mining area or near from highway [32]. The lead content in different parts respective order from high to low in roots, stems and leave, pericarps, flowers and seeds, in addition found on harvesting 105 days had the highest lead accumulation in whole plants [33] and [34].

The content of $\mathrm{Pb}$ metal in cattle that grazed in landfill is higher than outside the landfill. $\mathrm{Pb}$ metal is consumed indirectly by the cattle and will flow immediately through its feces. The content of $\mathrm{Pb}$ metal in feces cattle indicates that $\mathrm{Pb}$ is not absorbed in the body of the cattle, but transported by blood to organs of their body. As much as $95 \% \mathrm{~Pb}$ in the blood is bound by erythrocytes, $75-80 \% \mathrm{~Pb}$ is excreted through urine, $15 \%$ through feces and others through bile, sweat, hair and nails [35]. Only about 5-10\% of the amount of $\mathrm{Pb}$ entering through food or only $30 \%$ will be absorbed by the body, of which only $15 \%$ settles on body tissue and the rest will also be wasted along with metabolic waste materials such as feces and urine [3].

$\mathrm{Pb}$ metal can enter the body of the cattle, through food, drink and or air, can cause chronic poisoning if the metal accumulated for long term in body cattle, and will be acute poisoning if in high doses. In the long term, the Pc can be harmful to cattle health and can cause health problems even for humans who consume meat or processed products. Heavy metals can cause disturbance effects on human health, depending on the location and dose of exposure to metals. The limits of animal tolerance to heavy metals will vary because the animal's sensitivity to metal toxicity depends on the biological conditions of the animal concerned, i.e., age, health status, pregnancy, breastfeeding and environmental conditions [7]. Among the sign of $\mathrm{Pb}$ poisoning are heart attacks, anemia, kidney function, and decreased immunity, low birth weight, and premature birth due to elevated contents of $\mathrm{Pb}$ in the blood and urine [36], can affect digestion, heart, immune system, hemolymphs, reproduction, urinary system and system [37]. Hematopoietic systems are highly sensitive to the effects of $\mathrm{Pb}$ because they inhibit most of the enzymes that play a role in hem biosynthesis [38]. The study which was conducted in Para, Brazil shows there was cattle death caused by poisoning of energy storage machines that use batteries for power generation. The laboratory test results show the average $\mathrm{Pb}$ content in liver and renal of cattle was $93.91 \mathrm{mg} / \mathrm{kg}$ and $209.76 \mathrm{mg} / \mathrm{kg}$, respectively [39].

3.

4. Conclusion:

5. $\mathrm{Pb}$ content in the organic waste at Tamagapa landfill is feasible for cattle consumption but leachate water is not feasible for a source of drinking water. $\mathrm{Pb}$ contenton blood cattlegrazedinside and outside the landfill is differ respectively. However, the $\mathrm{Pb}$ contenton feces cattle in inside the landfill is higher than outside the landfill. Therefore, we need more research to know how long the cattle are grazed in the landfill.

\section{ACKNOWLEDGEMENT}

7. The authors would like to thank to the Rector of Hasanuddin University, Prof. Dr. Dwia Aries Tina Pulubuhu M.A. and Post Graduate Program of Animal Science Department, Hasanuddin University. And also thanks to author's supervisor and co-supervisor. Special thanks to Farmers of Tamangapa Landfill for sharing during this research. Other thanks to the technicians in the Chemical and Livestock Feed Laboratory, Hasanuddin Universityfor chemical analysis.

\section{REFERENCES}

[1] Zubair, A. and Haeruddin, 2012. The potential study of recycling waste at Tamanggapa Landfill Makassar City. Proceeding of Research Result of Faculty of Engineering, Civil Department, Hasanuddin University Makassar. 
[2] Department of Agriculture and Marine Makassar. 2015. Data number of farmers who raise cattle at Tamangapa Landfill (interview). Department of Agriculture and Marine Affairs, Makassar City.

[3] Palar, H., 2012. Heavy Metal Pollution and Toxicology. Rineka Cipta. Jakarta.

[4] Josthna, P., T. Geetharathan, P. Sujatha, G. Deepika, 2012. Accumulation of lead and cadmium in the organ and tissues of albino rat. International Journal of Pharmacy and Life Sciences, 3(12): 2186-2189.

[5] Milam, C., B.M. One, K.R. Dogara, Y.E. dan Yila, 2017. Assessment of heavy metals (As, Cd, Cr, Cu, Ni, $\mathrm{Pb}$ and $\mathrm{Zn}$ ) in blood samples of sheep and rabbits from Jimeta-yola, Adamawa State, Nigeria. IJAPBC 6(3): 160-166.

[6] Boucetta, S., H. Beldi, B. Draredja, 2016. Effects of metal pollution on the activities of Acetylcholinesterase and glutathione $-\mathrm{S}$ transferase in Phorcus (Osilinus) turbinatus (Gastropoda, Trochidae) of the coast EastAlgerian. Advances in Environmental Biology, 10(5): 46-60.

[7] Darmono, 2001. Environment and Pollution (Relation to Toxicology of Metal Compounds). UI Press. Jakarta.

[8] Purnama, A., F. Zakaria, H.D. Kusumaningrum, S. Hasan, 2014. Selected minerals in meat of cattle grazing in mine revegetation areas and safe consumption for human. Journal Food Science and Quality Management, 20: 18-24.

[9] Widowati, W., A. Sastiono, R.R. Jusuf, 2008. Metal Toxic Effects, Pollution, Prevention and Control. Andi, Yogyakarta.

[10] Sudarwin, 2008. Spatial analysis of heavy metal pollution ( $\mathrm{Pb}$ and $\mathrm{Cd}$ ) in river flow sediments from Jatibarang Landfill Semarang, Thesis, Post Graduate ProgramUniversity of Diponegoro, Semarang.

[11] Orisakwe, O.E., O.O. Oladipo, C.G. Ajaezi, A.N. dan Udowelle, 2017. Horizontal and vertical distribution of heavy metals in farm produce and livestock around lead-contaminated goldmine in Dareta and Abare, Zamfara State, Northern Nigeria.

[12] Abou-Arab, A.A.K., M.A. Abou Donia, Sherif R. Mohamed, A.K. Enab, 2015. Risk assessment of lead in egyptian vegetables and fruits from different environments. World Academy of Science, Engineering and Technology International Journal of Nutrition and Food Engineering, 9(3): 335-341.

[13] Solidum, J.M., M.J.D. De Vera, A.D.C. Abdulla, J.H. Evangelista and M.J.A.V. Nerosa, 2013. Quantitative analysis of lead, cadmium and chromium found in selected fish marketed in Metro Manila, Philippines. IJESDM, 4(2): 207-211.

[14][AOAC] Association of Official Agricultural Chemists, 1999. Metal in Plants and Pet Foods. Method 975.03. Chapter 3 p.3.

[15][NRC] National Research Council, 2000. Nutrient requirement of beef cattle. 7th: 69-89. ISBN : 0-30959241-0

[16] Indonesian National Standard, 2009. Maximum Limit of Heavy Metals In Food Contamination (SNI No.7387-2009). Jakarta.

[17] Wardhayani, S., 2006. Risk analysis of Pb toxic material pollution in beef cattle at Jatibarang Landfill PostGraduate Dipenegoro University, Semarang.

[18] Sudiyono, H.E., 2010. Study of the Potential of "Cempo" Surakarta Landfill as a Source of Cattle Feed. Caraka Tani XXV No.1 Maret 2010.

[19] Darmono, 2004. Environment and Pollution (Relation to Toxicology of Metal Compounds). UI Press. Jakarta.

[20] Purnama, A., 2014. The risks of heavy metal contamination in grass beef and alive in the area of mine revegetation. Thesis. Bogor Agricultural University. Bogor.

[21][NRC] National Research Council. (2005). Mineral tolerance of animals. Second Revised Edition. Washington, DC: The National Academies Press.

[22] Hasan, S., A. Natsir, A. Ako, A. Purnama, Y. Ishii, 2016. Evaluation of tropical grasses on mine revegetation for herbage supply to Bali cattle in Sorowako, South Sulawesi, Indonesia. Online Jurnal of Biological Sciences, 16(2): 102-106.

[23][WHO]World Health Organization, 2007. Water for Pharmaceutical Use. In: Quality Assurance of Pharmaceuticals: A Compendium of Guidelines and Related Materials. 2nd Updated Edn. World Health Organisation, Geneva (CH), 2: 170-187.

[24][NRC] National Research Council, 2011. Water requirements for beef cattle. Seventh reseived edition.Washington, DC: The National Academies Press. https://doi.org/10.17226/9825.

[25] Purnamasari, A.I., 2016. Age Relation With Heavy Metal Pb Contamination In The Blood and Animal Behavior Image of Bali Beef Cattle at Suwung Denpasar Landfill Post Graduate Faculty of Veterinary Medicine, Udayana University. Denpasar.

[26] Nwude, O.D., O.J. Babayemi, O.I. dan Abhulimen, 2011. Metal quantification in cattle: A case of cattle at slaughter at Ota Abattoir, Nigeria. Department of Chemical Sciences, Bells University of Technology, Ota, Ogun State, Nigeria. Journal of Toxicology and Environmental Health Sciences, 3(9): 271-274. 
[27] Siddiqui, M.F. and R.R. Gayatri, 2008. Lead an emerging threat to livestock. Veterinary College, Nagpur 440006, Maharashtra, India Veterinary, 1(7): 213-216.

[28] Suwaidah S.I., S.N. Achyadi, W. Cahyadi, 2014. Study of Heavy Metal Contamination from Packaging of Seconded Paper into Fried Food (the study of lead leached from waste paper packaging into fried foods). Center for Food and Drug Supervisor, POM and Pasundan University, Bandung.

[29] Kanayochukwu, N.J., O.O. Ebere, O.I. Obi, 2010. Heavy Metal Levels in Muscles of Some Fish Species from Aladja River; Warri, Nigeria: A Public Health Concern. Advances in Environmental Biology, 4(5): 125-130.

[30] Dai, Y.S., B. Jones, Kyung-Min Leeb, Wei Lib, L. Postc and J.T. Herrmana, 2016. Heavy metal contamination of animal feed in Texas. Journal of Regulatory Science, 4(1): 21-32.

[31] Irasanti, M., N.D. Santi, S. Dharma, 2012. Analysis of Pb content In liver from beef cattle in Deliserdang Regency, Medan. Jurnal Lingkungan dan Kesehatan Kerja, 4(1): 1-6.

[32] Milam, C., J.B. Dimas, A.L. Jang and E.J. Eneche, 2015. Determination of some heavy metals in vital organs of cattle and bulls at Jimeta abattoir, Yola, Adamawa State, Nigeria. American Chemical Science Journal, 8(4): 1-7.

[33] Jawad, I., 2016. Determination of Heavy Metals in Spices and Medical Herbs Available on the Iraq Market. Advance in Environmental Biology, 10(1): 66-69.

[34] Sukyanki, S., S. Theankingkaew, T. Panich-pat, 2016. Phytoaccumulation of s contaminated soil. Available on the Iraq Market. Advance in Environmental Biology, 10(10): 47-52.

[35] Ardianto, 2005

[36] Eslami, S., H.A. Moghaddam, N. Jafari, F.S. Nabavi, A.M. Ebrahimzadeh, 2011. Trace element level in different tissues of Rutilus frisii kutum Collected from Tajan River, Iran. Biological Trace Element Research, 143(2): 965-973.

[37] Assi, M.A., M.N.M. Hezmee, A.W. Haron, M.Y.M. Sabri, M.A. Rajion, 2016.The detrimentale effects of lead on human and animal health. Veterinary World, 9(6): 660-671.

[38] Siagian, D., 2008. Barriers of delta-aminolevulinic acid synthetase (-alad) enzyme activity in heme biosynthesis due to exposure to plumbum. VISION, 16(2): 490-497

[39] Gava, A., F.M. Salvarani and C.M.C. Oliveira, 2014. Lead poisoning in cattle and chickens in the state of Pará, Brazil. Pesquisa Veterinária Brasileira, 34(11): 1077-1080. 